\title{
Association of Dolichos biflorus lectin binding with full differentiation of bovine trophoblast cells
}

\author{
H. Nakano, A. Shimada, K. Imai, T. Takahashi and K. Hashizume* \\ Laboratory of Reproductive Biology and Technology, Department of Developmental Biology, \\ National Institute of Agrobiological Sciences, Ikenodai 2, Kukizaki, Ibaraki 305-8602, Japan
}

\begin{abstract}
Binucleate cells in ruminant placenta are differentiated from fetal mononucleate trophoblast cells and secrete many glycoproteins. This study characterized bovine placental binucleate cells in primary culture and a bovine trophoblastic cell line (BT-1) with an $\mathrm{N}$-acetylgalactosamine-binding lectin, Dolichos biflorus agglutinin (DBA). DBA specifically bound to the surface membrane and the cytoplasm of binucleate cells. Mononucleate epithelial cells and fibroblasts were free of DBA. DBApositive binucleate cells corresponded to the fully matured cells, producing placental lactogen, and the cytoplasm was devoid of cytokeratin. Binucleate cells assumed a flattened shape on a collagen substratum in an extended culture, and entered a dedifferentiated state with a degranulation of placental lactogen. In these flattened cells, DBA reactions were attenuated in the cytoplasm. DBA binding
\end{abstract}

\section{Introduction}

Binucleate cells are found in the fetal portion of the placenta in ruminants and primarily serve an endocrine function during pregnancy (for a review, see Wooding and Flint, 1994). These cells produce both peptide- and steroidhormones, such as placental lactogen (Duello et al., 1986; Wooding and Beckers, 1987; Anthony et al., 1995), prolactin-related protein-1 (PRP-1; Zieler et al., 1990; Kessler et al., 1991; Anthony et al., 1995), pregnancyassociated glycoproteins (PAGs; Zoli et al., 1991, 1992; Green et al., 2000), oestradiol (Matamoros et al., 1994) and progesterone (Reimer et al., 1985; Wango et al., 1991). Binucleate cells are thought to be produced by acytokinesis (Wimsatt, 1951; Björkman, 1968; Klisch et al., 1999b) and by subsequent endoreduplication (Klisch et al., 1999a) of mononuclear trophoblastic epithelial cells, and they represent about $20 \%$ of the trophoblastic epithelial cells throughout gestation (Wooding and Wathes, 1980; Wooding, 1982). Binucleate cells show a unique migration with the maintenance of tight junctions between adjacent trophoblastic epithelial cells (Wooding et al., 1994). The migrating cells are destined to fuse with uterine epithelial

*Correspondence.

Email: kazuha@affrc.go.jp in BT-1 was subsequently examined. BT-1 was derived from blastocysts produced in vitro and is trophectodermal as shown by the expression of cytokeratin. BT-1 was able to differentiate into placental lactogen-producing binucleate cells on a collagen gel substratum. Cytokeratin expression in BT-1 was downregulated with the differentiation into binucleate cells. However, DBA bound to neither mononucleate nor the differentiated binucleate cells in BT-1. These results indicate that binucleate cells in vivo but not binucleate cells derived from BT-1, specifically developed glycoconjugates recognized by DBA. The glycoconjugate expression was associated with fully differentiated cells. The onset of DBA binding in binucleate cells coincides with placental development, and binucleate cells differentiated from BT-1 cell cultures may reflect those cells at earlier stages of gestation.

cells and secrete hormones into the maternal circulation (Wooding and Wathes, 1980; Wooding, 1982; Wooding and Beckers, 1987). These hormones are thought to influence maternal metabolism (Anthony et al., 1995).

Histochemistry reveals that the granules of binucleate cells are heavily glycosylated as shown by periodicacid-Schiff staining (Wimsatt, 1951) and by lectin binding (Munson et al., 1989; Lehmann et al., 1992; Jones et al., 1994). Several studies (Munson et al., 1989; Lehmann et al., 1992; Jones et al., 1994) have demonstrated consistently that bovine binucleate cells in placental tissue (but not before day 40 of gestation, Lehmann et al., 1992) stain intensely with Dolichos biflorus agglutinin (DBA), a plant lectin with specificity for terminal non-reducing $\alpha$-linked $\mathrm{N}$-acetylgalactosamine glycoresidues (Etzler and Kabat, 1970). The molecular structure and the function of glycoconjugates recognized in bovine binucleate cells by DBA have not been elucidated, but DBA-binding activity provides a useful marker for binucleate cells, and may reflect the state of their differentiation.

Nakano et al. (2001) established a primary culture system of binucleate cells from bovine placental tissue and found that fully matured binucleate cells with placental lactogen productivity did not have cytokeratin in the cytoplasm, but immature or dedifferentiated binucleate cells without placental lactogen expressed cytokeratin. In the present study, a detailed analysis of DBA binding was 

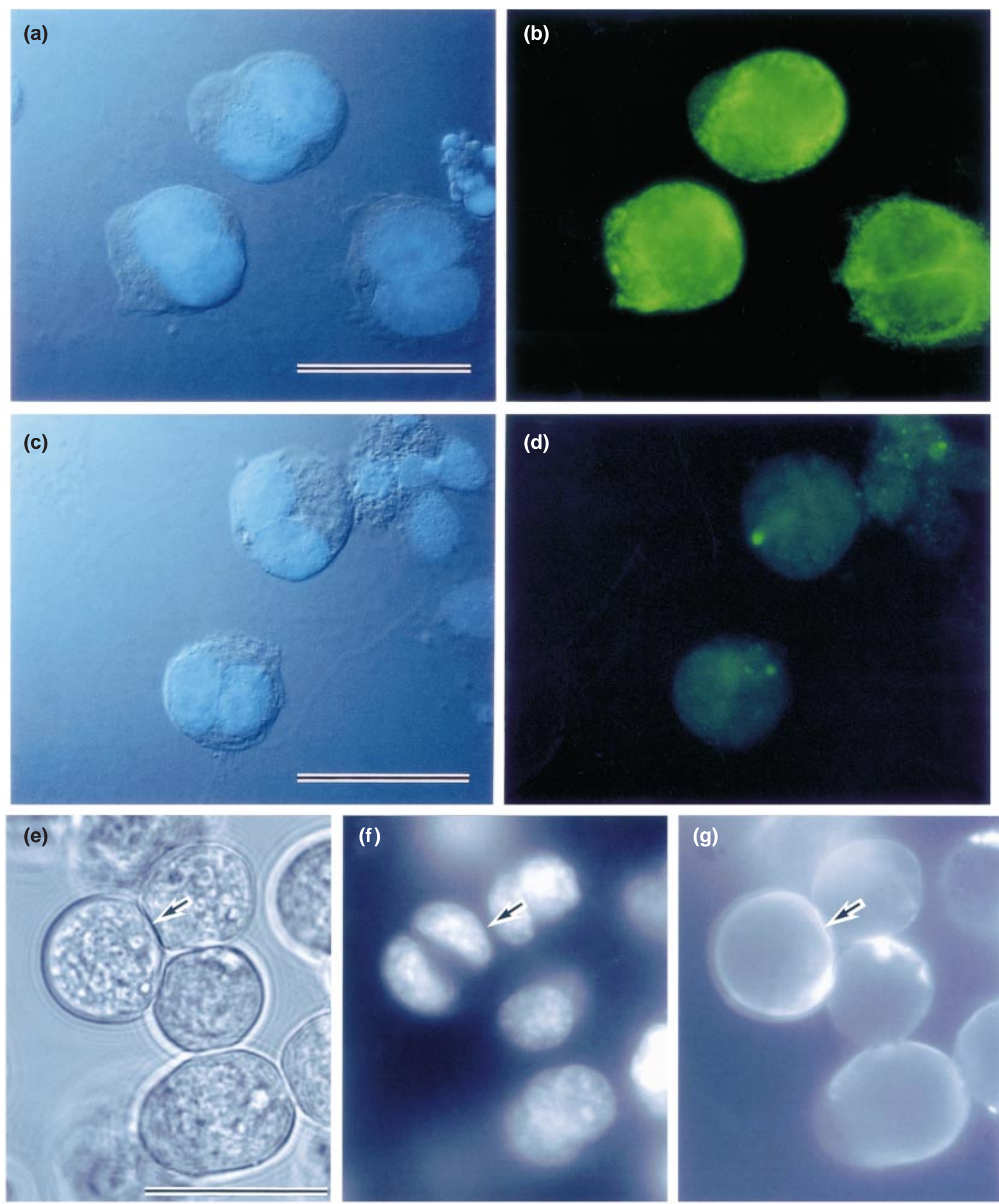

Fig. 1. Dolichos biflorus agglutinin (DBA) staining of bovine placental binucleate cells in primary culture. After 1 day in culture, binucleate cells were incubated with fluorescein isothiocyanate (FITC)-conjugated DBA in the (b) absence or (d) presence of 0.2 mol $N$ acetylgalactosamine $\mathrm{I}^{-1}$. Nomarski differential images (a) and (c) are the same fields of images as (b) and (d), respectively. Nuclei were stained with Hoechst 33342 and the images were merged into Nomarski differential images. (e-g) FITC-conjugated DBA staining in live 
performed on binucleate cells in primary culture and intact tissue in relation to their placental lactogen and cytokeratin expression. Cell cultures allow determination of which types of cell (especially mono- or binucleate cells) are stained with DBA, as the whole appearance of the individual cell can be seen in cell cultures, unlike in tissue sections. In addition, DBA binding on a bovine trophoblastic cell line (BT-1) established from blastocysts produced in vitro was examined (Shimada et al., 2001). This cell line is of interest as some cells can transform into placental lactogen-producing binucleate cells when they are cultured on a collagen gel substratum (Nakano et al., 2002).

\section{Materials and Methods}

\section{Preparation of bovine placental binucleate cells}

Bovine (Bos taurus) placentomes were obtained from Holstein cows from mid-gestation to term (fetal crown-rump lengths: 20, 35, 40, 52, 78 and $88 \mathrm{~cm}$ ) from the local abattoir. Binucleate cells were isolated and cultured as described by Nakano et al. (2001). In brief, fetal cotyledonary tissue was separated manually from placentomes, washed three times with PBS (Nissui, Tokyo) and cut into small pieces. The pieces of tissue were incubated with $0.1 \%(\mathrm{w} / \mathrm{v})$ collagenase (S-1; Nitta Gelatin, Osaka) in Dulbecco's modified Eagle's/F-12 medium (DME/F-12, Gibco, Rockville, MD) containing 100 iu penicillin $\mathrm{ml}^{-1}$ and $100 \mu \mathrm{g}$ streptomycin $\mathrm{ml}^{-1}$ (Sigma, St Louis, MO), supplemented with $5 \%(\mathrm{v} / \mathrm{v})$ fetal bovine serum (Sigma) for $15-25 \mathrm{~min}$ at $37^{\circ} \mathrm{C}$. The digested tissue was filtered through a series of 300 and $180 \mu \mathrm{m}$ pore stainless steel meshes to remove undigested tissue. The filtrate was washed with the medium and layered on discontinuous Percoll (Amersham Pharmacia Biotech, Uppsala) gradients with isopycnic densities at $1.03-1.08 \mathrm{~g} \mathrm{ml}^{-1}$, and centrifuged at $800 \mathrm{~g}$ for $20 \mathrm{~min}$. Binucleate cells sedimented at the interface between 1.05 and $1.06 \mathrm{~g} \mathrm{ml}^{-1}$ were collected, washed and resuspended in the medium. The cell suspension was plated on collagen-gel mounted coverslips and cultured at $37^{\circ} \mathrm{C}$ in an atmosphere of $5 \%$ $(\mathrm{v} / \mathrm{v}) \mathrm{CO}_{2}$.

\section{Culture of $B T-1$}

BT-1 was established from blastocysts produced in vitro (Shimada et al., 2001). BT-1 was cultured in DME/F-12 medium containing $100 \mathrm{iu}$ penicillin $\mathrm{ml}^{-1}$ and $100 \mu \mathrm{g}$ streptomycin $\mathrm{ml}^{-1}$, supplemented with $10 \%(\mathrm{v} / \mathrm{v})$ fetal bovine serum alone, or with 10\% fetal bovine serum, 50\% $(\mathrm{v} / \mathrm{v})$ bovine uterine fibroblast conditioned medium, $50 \mu \mathrm{mol} \beta$-mercaptoethanol $\mathrm{I}^{-1}$ and $1 \mu \mathrm{g}$ heparin $\mathrm{ml}^{-1}$. The uterine fibroblast conditioned medium promoted the growth of BT-1 (Shimada et al., 2001) and was prepared by incubating confluent bovine uterine fibroblasts in DME/F12 supplemented with $10 \%$ fetal bovine serum for 2 or 3 days. The conditioned medium was filtered $(0.22 \mu \mathrm{m})$ and stored at $-20^{\circ} \mathrm{C}$ until use.

A monolayer of the confluent BT-1 cell sheet was mechanically passaged in and out with a pipette (pore size $2 \mathrm{~mm}$ ). The dissociated cell clumps in the culture medium were plated on collagen-coated flasks. The cell clumps attached to the flasks and proliferated to form a monolayer again. Successful passages were also achieved by transferring multicellular vesicles formed spontaneously from the cell colony (Shimada et al., 2001). These vesicles $(100 \mu \mathrm{m}$ to $1 \mathrm{~mm}$ in diameter) floating in the culture medium were collected with $180 \mu \mathrm{m}$ pore stainless steel mesh. The vesicles were resuspended in fresh medium and plated on a new collagen-coated flask. The vesicles attached to the collagen substratum, flattened out and regenerated the cell sheet.

The muticellular vesicles were cultured on collagengel mounted coverslips in DME/F-12 supplemented with $10 \%(\mathrm{v} / \mathrm{v})$ fetal bovine serum to induce differentiation into binucleate cells. After $>10$ days, clusters of binucleate cells appeared in the cell colony (Nakano et al., 2002).

\section{Preparation of collagen-mounted culture flasks and coverslips}

The collagen-coated flasks were prepared by incubating a tenfold diluted solution of acid soluble pig type I collagen (type I-A, $3 \mathrm{mg} \mathrm{ml}^{-1}$, Nitta Gelatin, Osaka) in culture flasks for $>1 \mathrm{~h}$ at room temperature (about $26^{\circ} \mathrm{C}$ ). The culture flasks were washed with DME/F-12 and used for cell culture. Collagen-gel mounted coverslips were prepared using the collagen (type I-A) according to the manufacturer's instructions. Eight volumes of the collagen solution was mixed with one volume of a tenfold concentrated Hepes-buffered physiological salt solution

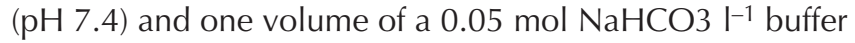
solution in a conical tube on ice. A drop of the mixed gel solution was dispensed on to a horizontal glass coverslip (15 or $25 \mathrm{~mm}$, Matsunami) and incubated at $37^{\circ} \mathrm{C}$ for 20-30 min until use in cell culture.

\section{Lectin and immunocytochemical staining}

Cells cultured on collagen-gel mounted coverslips were fixed with $4 \%(\mathrm{w} / \mathrm{v})$ paraformaldehyde in $0.1 \mathrm{~mol}$ phosphate buffer $\mathrm{I}^{-1}$ at $4^{\circ} \mathrm{C}$ for $15 \mathrm{~min}$. After three washes with PBS, the cells on the coverslips were immersed in

binucleate cells just after isolation. (e) Phase contrast, ( $\mathrm{f}$ ) Hoechst 33342 and (g) FITC-conjugated DBA images in the same field. The surface membrane of a binucleate cell is indicated by an arrow. Binucleate cells were prepared from placentomes at fetal crown-rump lengths of $35 \mathrm{~cm} \mathrm{(a-d)} \mathrm{and} 78 \mathrm{~cm}(\mathrm{e}-\mathrm{g})$. Scale bars represent $30 \mu \mathrm{m}$. 

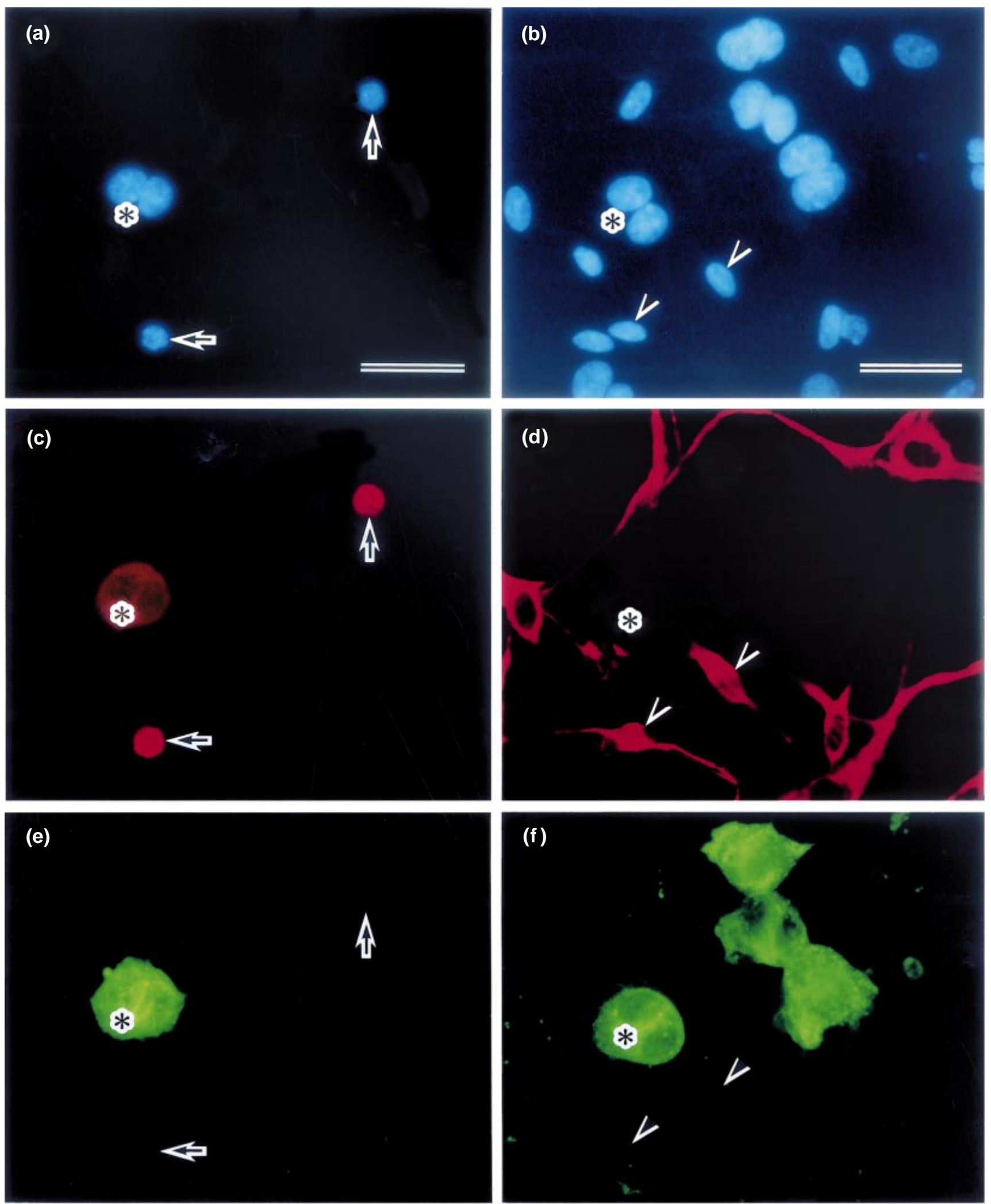

Fig. 2. Dilichos biflorus agglutinin (DBA) staining of epithelial cells and fibroblasts contaminating binucleate cell preparations. After 1 day in culture, cells were double-stained with $(\mathrm{a}, \mathrm{c}, \mathrm{e})$ monoclonal anti-cytokeratin antibody (red) and fluorescein isothiocyanate (FITC)conjugated DBA (green), or $(b, d, f)$ monoclonal anti-vimentin antibody (red) and FITC-conjugated DBA (green). (a,b) Nuclei were stained 
acetone at $-30^{\circ} \mathrm{C}$ for $5 \mathrm{~min}$. Lectin staining was performed by incubating $10 \mu \mathrm{g}$ fluorescein isothiocyanate-conjugated DBA ml-1 (FITC-conjugated DBA; Vector, Burlingame, CA) in the reaction solution (PBS containing 1\% $(\mathrm{w} / \mathrm{v}) \mathrm{BSA}$ and $\left.0.05 \%(\mathrm{w} / \mathrm{v}) \mathrm{NaN}_{3}\right)$ for $1 \mathrm{~h}$ at room temperature. For absorption control staining, $0.2 \mathrm{~mol} \mathrm{~N}$-acetylgalactosamine $\mathrm{I}^{-1}$ (Sigma) was added to the FITC-conjugated DBA solution. Nuclei were stained with Hoechst 33342 (Molecular Probes, Eugene, OR; final concentration $5 \mu \mathrm{g} \mathrm{ml}^{-1}$ ). After three washes with PBS, the cells were mounted using Perma Fluor, and viewed under an epifluorescence microscope (Zeiss Axobart).

Double staining was performed using FITC-conjugated DBA combined with either anti-cytokeratin, anti-vimentin or anti-placental lactogen antibody. Cells cultured on collagen-gel mounted coverslips were fixed in $4 \%(\mathrm{w} / \mathrm{v})$ paraformaldehyde and permeabilized with cold acetone as described above. The cells were blocked with $10 \%(\mathrm{v} / \mathrm{v})$ normal goat serum in PBS for $30 \mathrm{~min}$ at room temperature. Incubation with monoclonal mouse anti-cytokeratin antibody (ready to use, AE1/AE3; Nichirei, Tokyo), monoclonal mouse anti-vimentin antibody $(1: 800$, clone V9; DAKO, Glostrup) or monoclonal mouse anti-PL antibody (1:1000 or 1:10000; Nakano et al., 2001; Takahashi et al., 2001) was carried out for $2 \mathrm{~h}$ at room temperature. After three washes with PBS, a mixture of Alexa 546-conjugated goat anti-mouse IgG antibody (Alexa 546 anti-mouse IgG, 1:400; Molecular Probes), FITCconjugated DBA and Hoechst 33342 in the reaction solution was applied for $1 \mathrm{~h}$ at room temperature. After three washes with PBS, the cells were mounted and viewed under the Zeiss Axobart microscope.

Double staining with monoclonal mouse anticytokeratin antibody (AE1/AE3) and polyclonal rabbit antiPL antibody (1:8000) was performed as described by Nakano et al. (2001). The signals were visualized using Alexa 546 anti-mouse IgG and Alexa 488-conjugated goat anti-rabbit $\lg \mathrm{G}$ antibody (Alexa 488 anti-rabbit IgG, 1:200; Molecular Probes).

These staining techniques were also applied to bovine placenta tissue sections with some modifications. Placentomes from two Holstein cows (crown-rump lengths $20 \mathrm{~cm}$ and $40 \mathrm{~cm}$ ) and three Japanese black cows at days 59, 104 and 150 of gestation (crown-rump lengths of $6.5,21.0$ and $39.0 \mathrm{~cm}$, respectively) were frozen. Cryosections $(6-8 \mu \mathrm{m}$ in thickness) were cut with a cryostat (HM500, MICROM) and mounted on 3-aminopropyltriethoxysilane-coated glass slides (Matsunami). The sections were fixed in $4 \%(\mathrm{w} / \mathrm{v})$ paraformaldehyde for $15 \mathrm{~min}$ at room temperature and stained as described above, except for incubation of primary antibodies overnight at $4^{\circ} \mathrm{C}$.

\section{DBA staining in live binucleate cells}

Just after isolation, binucleate cell preparations were incubated with $10 \mu \mathrm{g}$ FITC-conjugated DBA ml-1 and $10 \mu \mathrm{g}$ Hoechst $33342 \mathrm{ml}^{-1}$ in $5 \%(\mathrm{v} / \mathrm{v})$ fetal bovine serum DME/F12 medium for $30 \mathrm{~min}$ at room temperature. After the cells were washed with the medium, they were observed under an inverted epifluorescence microscope (IX70, Olympus).

\section{Results}

\section{DBA binding in bovine placental binucleate cells in primary culture}

A binucleate cell rich fraction (approximately 50\% binucleate cells) was obtained by collagenase digestion and Percoll density gradient centrifugation (Nakano et al., 2001). The fraction was plated out on collagen-gel mounted coverslips. After day 1 of culture, binucleate cells were easily recognized by their oval shape $(20-30 \mu \mathrm{m}$ in diameter) and two large nuclei (Fig. 1a,c). FITC-conjugated DBA bound to the whole cytoplasm of binucleate cells (Fig. 1b). DBA staining was attenuated in the presence of its competing sugar, $\mathrm{N}$-acetylgalactosamine (Fig. 1d), indicating that the binding was specific. When DBA was applied to live binucleate cells just after isolation (Fig. $1 \mathrm{e}-\mathrm{g}), \mathrm{DBA}$ bound to the surface membrane of binucleate cells (Fig. 1g). Staining of DBA combined with either anticytokeratin or anti-vimentin was used to assess the binding to mononucleate epithelial cells and fibroblasts in the binucleate cell preparations. Mononucleate epithelial cells (Fig. 2a,c,e) and fibroblasts (Fig. 2b,d,f) were marked selectively by anti-cytokeratin (Fig. 2c) and anti-vimentin (Fig. 2d), respectively. Almost all (>95\%) of the epithelial cells (Fig. 2e) and all of the fibroblasts (Fig. 2f) were free of DBA, whereas binucleate cells were stained strongly (Fig. $2 \mathrm{e}, \mathrm{f})$. These results provide clear evidence that DBA specifically labels binucleate cells in primary culture.

Binucleate cells are thought to be produced by the acytokinesis of mononucleate epithelial cells (Wimsatt, 1951; Björkman, 1968; Klisch et al., 1999b), and mature to develop secretory machinery for hormone production. Nakano et al. (2001) demonstrated that the cytoplasm of fully matured binucleate cells with placental lactogen productivity did not contain cytokeratin, but that the immature or dedifferentiated cells without placental lactogen expressed cytokeratin. Double staining of DBA and placental lactogen in binucleate cells prepared from three different pregnancies was performed to examine the relationship between DBA binding activity and the maturity of the cell. After day 1 of culture, most $(>80 \%)$ of the binucleate cells with an oval shape were placental

with Hoechst 33342. (a,c,e) Mononucleate epithelial cells (arrows) and (b,d,f) fibroblasts (arrowheads) are marked by (c) anti-cytokeratin and $(\mathrm{d})$ anti-vimentin, respectively. (a-f) Binucleate cells are indicated by asterisks. Binucleate cells were prepared from placentomes at crown-rump lengths of $35 \mathrm{~cm}(\mathrm{a}, \mathrm{c}, \mathrm{e})$ and $20 \mathrm{~cm}(\mathrm{~b}, \mathrm{~d}, \mathrm{f})$. Scale bars represent $30 \mu \mathrm{m}$. 

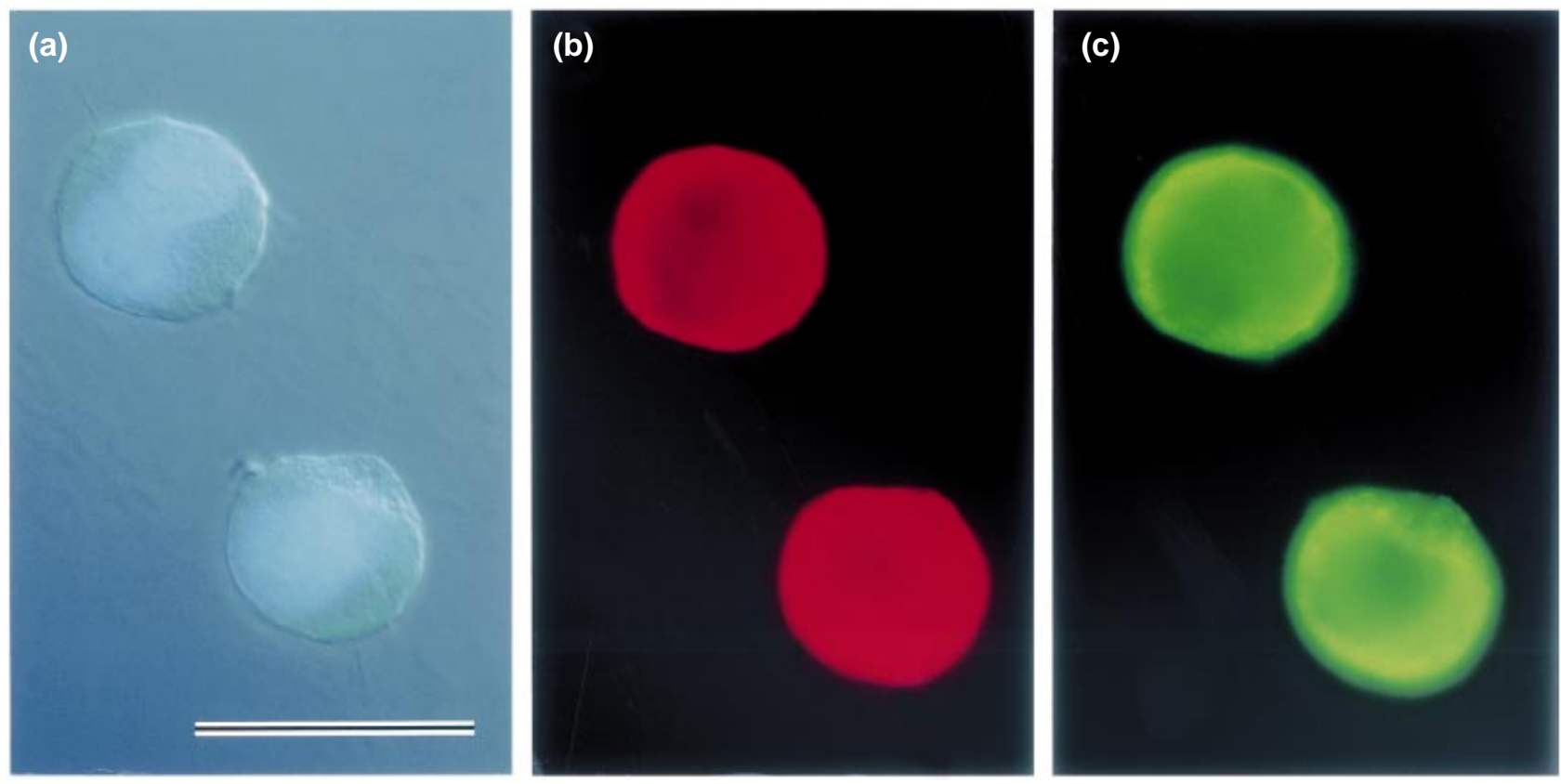

Fig. 3. Double staining for Dolichos biflorus agglutinin (DBA) and placental lactogen (PL) in binucleate cells in primary culture. After 1 day in culture, binucleate cells were double-stained with (b) monoclonal anti-PL antibody (red) and (c) fluorescein isothiocyanate (FITC)-conjugated DBA (green). (a) Nuclei were stained with Hoechst 33342 and the image was merged into the Nomarski differential image. Binucleate cells were prepared from placentomes at a crown-rump length of $52 \mathrm{~cm}$. Scale bar represents $30 \mu \mathrm{m}$.

Table 1. Frequency of bovine placental binucleate cells labelled with Dolichos biflorus agglutinin (DBA) and placental lactogen (PL)

\begin{tabular}{|c|c|c|c|c|c|}
\hline & $\mathrm{PL}(+) / \mathrm{DBA}(+)$ & $\mathrm{PL}(+) / \mathrm{DBA}(-)$ & $\mathrm{PL}(-) / \mathrm{DBA}(+)$ & $\mathrm{PL}(-) / \mathrm{DBA}(-)$ & Total number \\
\hline Sample 1 & 119 (98.4) & $0(0.0)$ & $1(0.8)$ & $1(0.8)$ & $121(100.0)$ \\
\hline Sample 2 & $124(82.7)$ & $0(0.0)$ & $21(14.0)$ & $5(3.3)$ & $150(100.0)$ \\
\hline Sample 3 & $75(74.3)$ & $6(5.9)$ & $10(9.9)$ & $10(9.9)$ & $101(100.0)$ \\
\hline
\end{tabular}

Binucleate cells from three different pregnancies (fetal crown-rump lengths: sample $1=20 \mathrm{~cm}$, sample $2=52 \mathrm{~cm}$, sample $3=88 \mathrm{~cm}$ ) were double-stained with DBA and PL after 1 day in culture. Binucleate cells of an oval shape were counted to classify PL-positive and DBA-positive $(\mathrm{PL}(+) / \mathrm{DBA}(+))$, PL-positive and DBA-negative $(\mathrm{PL}(+) / \mathrm{DBA}(-))$, $\mathrm{PL}$-negative and DBA-positive $(\mathrm{PL}(-) / \mathrm{DBA}(+))$, and $\mathrm{PL}$-negative and DBA-negative $(\mathrm{PL}(-) / \mathrm{DBA}(-))$ populations. Numbers in parentheses denote the percentage.

Table 2. Frequency of bovine placental binucleate cells labelled with Dolichos biflorus agglutinin (DBA) and cytokeratin (CK)

\begin{tabular}{|c|c|c|c|c|c|}
\hline & $\mathrm{CK}(+) / \mathrm{DBA}(+)$ & $\mathrm{CK}(+) / \mathrm{DBA}(-)$ & $\mathrm{CK}(-) / \mathrm{DBA}(+)$ & $\mathrm{CK}(-) / \mathrm{DBA}(-)$ & Total number \\
\hline Sample 1 & $6(4.7)$ & $2(1.6)$ & 119 (92.9) & $1(0.8)$ & $128(100.0)$ \\
\hline Sample 2 & $10(9.3)$ & $4(3.7)$ & $93(87.0)$ & $0(0.0)$ & 107 (100.0) \\
\hline Sample 3 & $23(13.4)$ & $21(12.2)$ & $126(73.2)$ & $2(1.2)$ & $172(100.0)$ \\
\hline
\end{tabular}

Binucleate cells from three different pregnancies (fetal crown-rump lengths: sample $1=20 \mathrm{~cm}$, sample $2=52 \mathrm{~cm}$, sample $3=88 \mathrm{~cm}$ ) were double-stained with DBA and CK after one day in culture. Binucleate cells of an oval shape were counted to classify CK-positive and DBA-positive $(C K(+) / D B A(+))$, CK-positive and DBA-negative $(\mathrm{CK}(+) / \mathrm{DBA}(-))$, CK-negative and DBA-positive $(\mathrm{CK}(-) / \mathrm{DBA}(+))$, and CK-negative and DBA-negative $(\mathrm{CK}(-) / \mathrm{DBA}(-))$ populations. Numbers in parentheses denote the percentage.

lactogen-positive (Fig. 3b), and almost all of these cells were co-stained with DBA (Fig. 3c). Similar observations were obtained from three different preparations (Table 1). Some placental lactogen-negative binucleate cells were stained by DBA, but such populations were small and variable between different preparations $(0.8-14.0 \%$ of total cells, Table 1). In these cells, DBA binding was localized at the surface membrane and the cytoplasm, but in some cells 

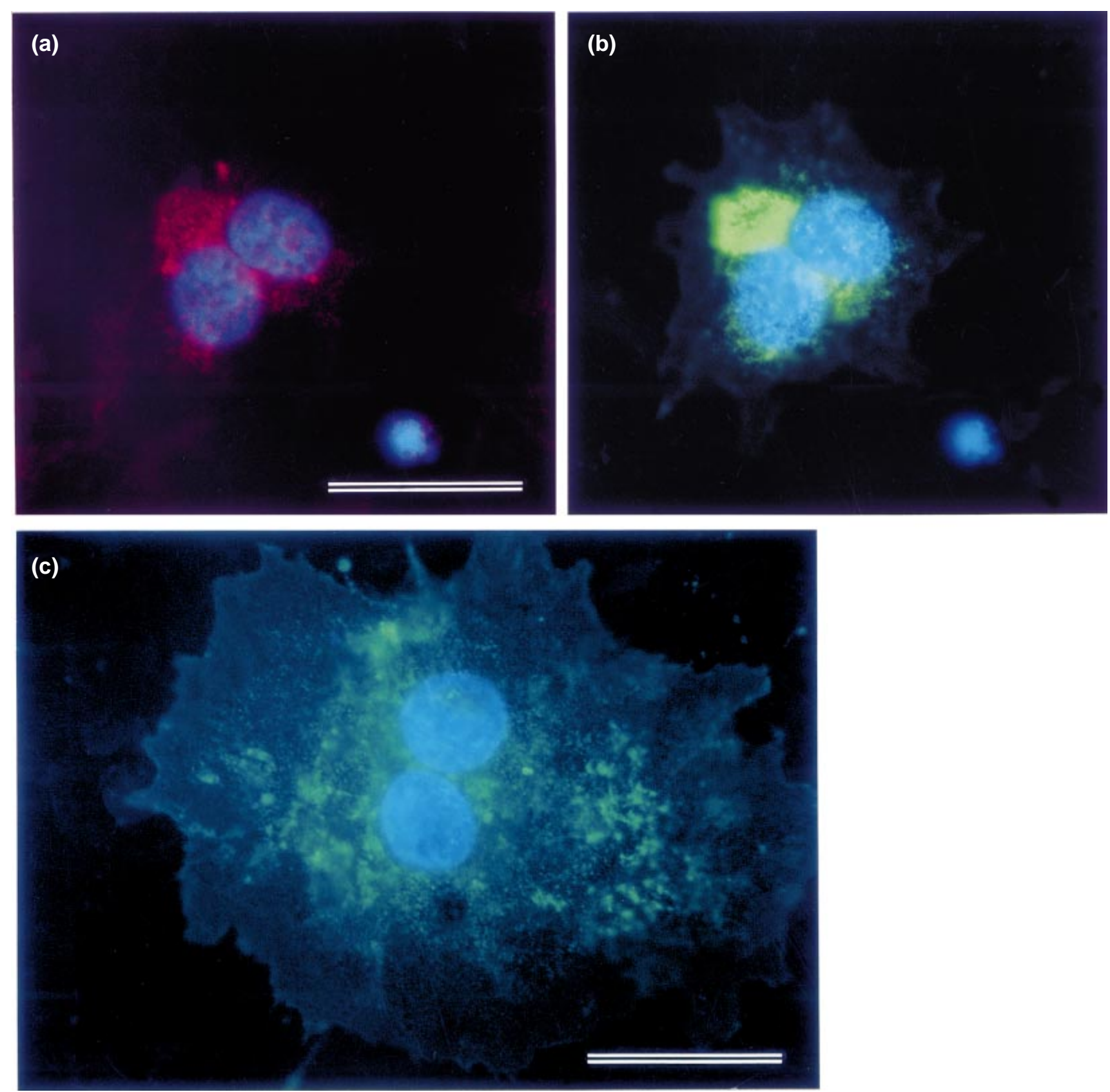

Fig. 4. Dolichos biflorus agglutinin (DBA) staining of flattened binucleate cells. Double staining with (a) monoclonal anti-placental lactogen (PL) antibody (red) and (b) fluorescein isothiocyanate (FITC)-conjugated DBA (green) was performed in binucleate cell of a flattened shape after 1 day in culture. (c) DBA staining of flattened binucleate cell after 3 days in culture. Binucleate cells were prepared from placentomes at a crown-rump length of $40 \mathrm{~cm}$. Scale bars represent $30 \mu \mathrm{m}$.

only to the surface membrane. Double staining for DBA and cytokeratin indicated that DBA-positive signals were mainly detected in the binucleate cells without cytokeratin (Table 2 ). These results indicated that the DBA binding activity was associated with the state of differentiation of the binucleate cell; DBA predominantly recognized fully matured binucleate cells with placental lactogen-positive and cytokeratin-negative signals.
Some binucleate cells had extended on the collagen substratum after day 1 of culture, and assumed a flattened shape (Fig. 4a,b). In these cells the expression of placental lactogen was downregulated (Fig. 4a). The cytoplasmic staining of DBA was also attenuated with a change in shape, and the DBA signal was localized to the peri-nuclear region (Fig. 4b). After day 4 in culture, most binucleate cells had assumed a flattened shape with a downregulated expression 

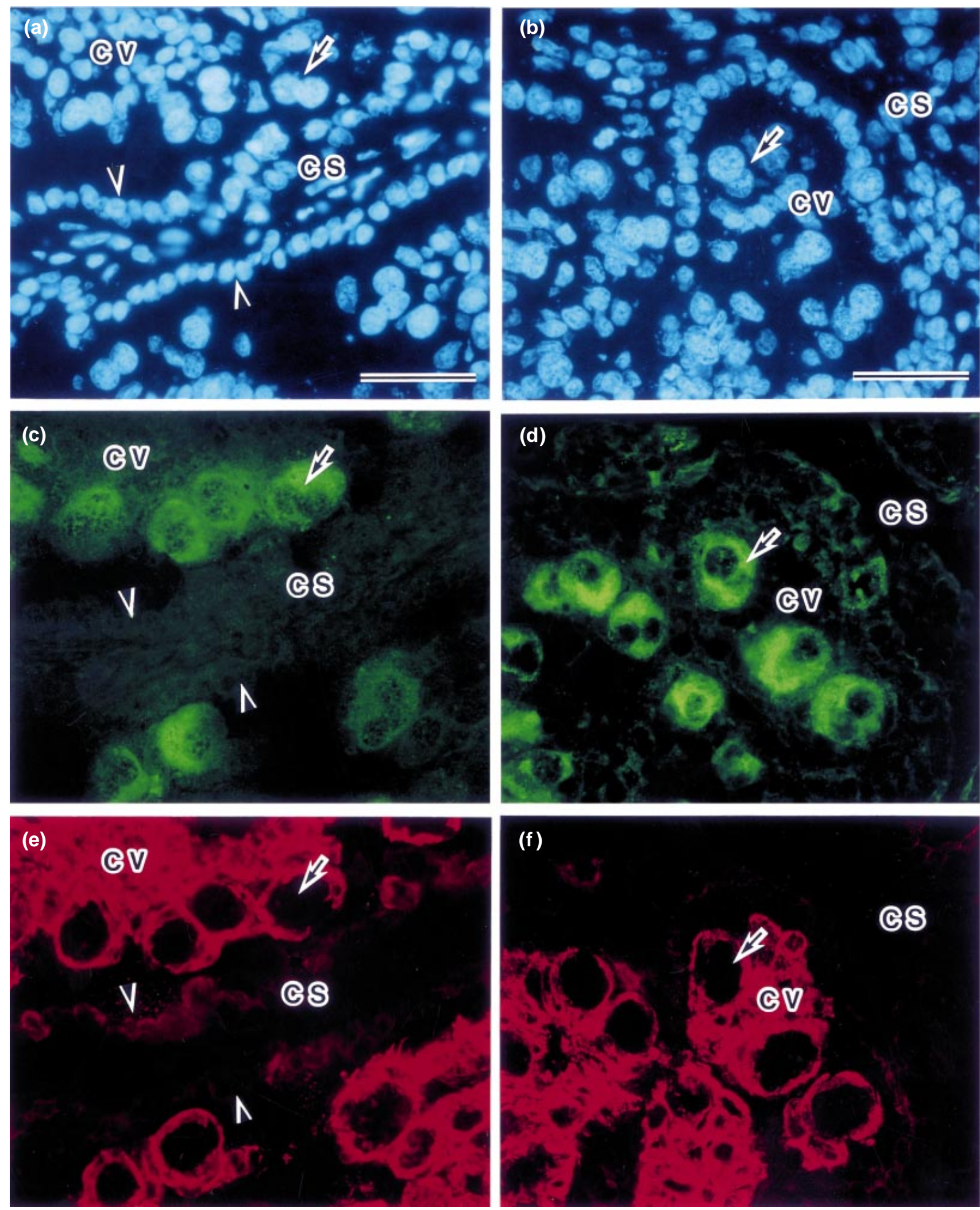

(f)

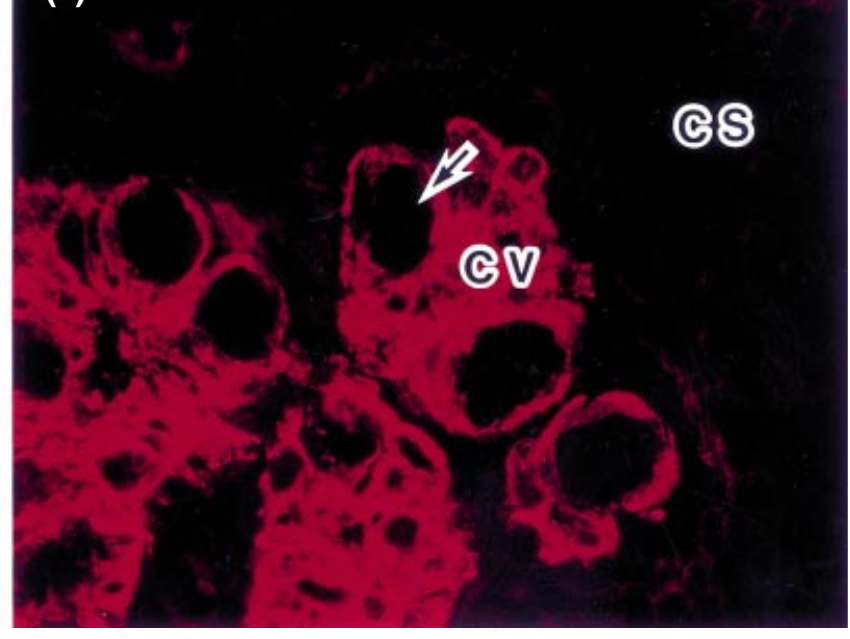

Fig. 5. Bovine placenta tissue stained with placental lactogen (PL), Dolichos biflorus agglutinin (DBA) and cytokeratin. Tissue sections of placentome at day 59 of gestation were double-stained with (a,c,e) polyclonal anti-PL (green) and monoclonal anti-cytokeratin antibodies (red) or with (b,d,f) fluorescein isothiocyanate (FITC)-conjugated DBA (green) and the anti-cytokeratin antibody (red). (a,b) Nuclei were stained with Hoechst 33342. (a-f) A binucleate cell in chorionic villi (CV) is indicated by an arrow. (a,c,e) Uterine epithelial cell layers in caruncular septa (CS) are indicated by arrowheads. Scale bars represent $50 \mu \mathrm{m}$. 

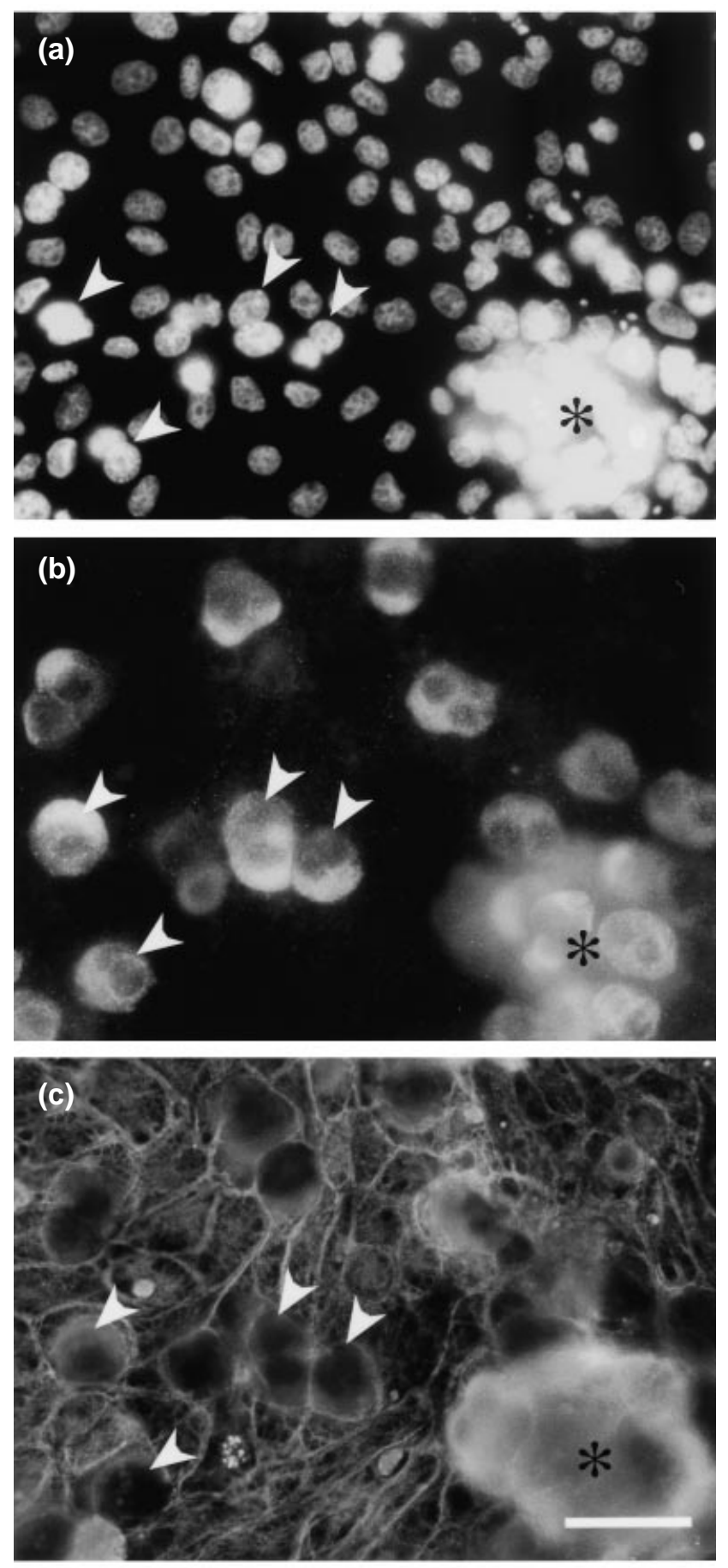

Fig. 6. Double staining for placental lactogen (PL) and cytokeratin in binucleate cells differentiated from the bovine trophoblast cell line (BT-1). After 15 days in collagen gel culture, BT-1 cells were double-stained with (b) polyclonal anti-PL and (c) monoclonal anti-cytokeratin antibodies. (a) Nuclei were stained with Hoechst 33342. Some differentiated binucleate cells are indicated by arrowheads. (a-c) A cluster of binucleate cells formed on the cell sheet is indicated by an asterisk. Scale bar represents $50 \mu \mathrm{m}$. of placental lactogen (Nakano et al., 2001). The DBA signal was further attenuated, and appeared sparsely throughout the cytoplasm (Fig. 4c). The results indicated that a decrease in DBA binding activity and placental lactogen immunoreactivity in binucleate cells coincided with a flattened shape in a dedifferentiated state.

\section{DBA binding in bovine placental tissue}

Tissue sections of bovine placentome were examined at day 59 of gestation, as DBA binding to binucleate cells has been observed at day 40 of gestation (Lehmann et al., 1992). After double staining of anti-placental lactogen and anti-cytokeratin (Fig. 5a,c,e), binucleate cells labelled with anti-placental lactogen (Fig. 5c) were devoid of anticytokeratin staining (Fig. 5e), whereas adjacent mononucleate trophoblast cells in chorionic villi were stained intensely with anti-cytokeratin. Reduced staining of anticytokeratin was observed in the uterine epithelial cell layer of caruncular septa (Fig. 5e). DBA staining combined with either anti-placental lactogen or anti-cytokeratin (Fig. 5b,d,f) showed that the cytoplasm of binucleate cells (but not mononucleate trophoblast cells) in chorionic villi was stained intensely with DBA (Fig. 5d), and that these cells had placental lactogen-positive (data not shown) and cytokeratin-negative signals (Fig. 5f). Uterine epithelial cells in caruncular septa were also stained somewhat with DBA (Fig. 5d). Similar observations were obtained with placentomes at later stages of gestation (approximately day 100 and day 150), except that there was more intense staining of DBA at the basal region of uterine epithelial cells in caruncular septa (data not shown). These results confirm the findings of the present study in primary cell cultures in which DBA bound to binucleate cells with placental lactogen-positive and cytokeratin-negative signals.

\section{$D B A$ binding in $B T-1$}

BT-1 is a bovine trophoblastic cell line derived from blastocysts produced in vitro, and its trophectodermal properties are characterized by the expression of cytokeratin (Shimada et al., 2001; Nakano et al., 2002). Some BT-1 cells (2-3\%) were able to differentiate into binucleate cells when cultured on a collagen gel substratum (Nakano et al., 2002) (Fig. 6). These binucleate cells were often observed in the stratified area of the cell colony (Fig. 6). The binucleate cells had an increased DNA content presumably due to endoreduplication (Nakano et al., 2002), and many of the cells produced placental lactogen (Nakano et al., 2002) (Fig. 6b). In the present study, the expression of cytokeratin filaments in the binucleate cells was often downregulated in the cytoplasm like those in vivo (Fig. 6c). Double staining of DBA and placental lactogen revealed that DBA did not bind to either the mononucleate or the differentiated binucleate cells irrespective of placental lactogen immunoreactivity (Fig. 7). These results indicate that binucleate cells in BT-1 were similar to those cells in 

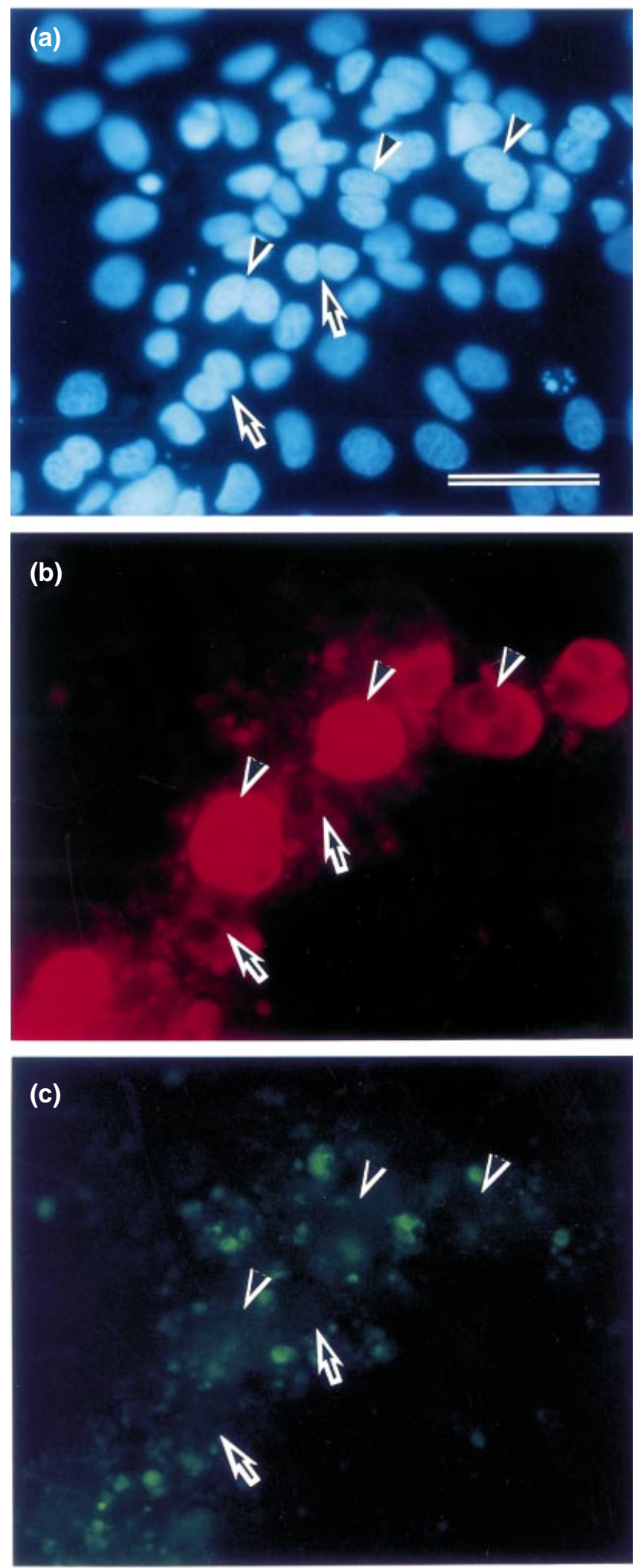

Fig. 7. Double staining for placental lactogen (PL) and Dolichos biflorus agglutinin (DBA) in binucleate cells differentiated from the bovine trophoblast cell line (BT-1). After 17 days in collagen gel culture, BT-1 cells were double-stained with (b) monoclonal anti- vivo in terms of placental lactogen and cytokeratin expression, but were distinct in DBA staining.

\section{Discussion}

The present study characterized bovine placental binucleate cells in primary culture and a bovine trophoblastic cell line (BT-1) with a $\mathrm{N}$-acetylgalactosaminebinding lectin, DBA. DBA specifically recognizes a terminal non-reducing $\alpha$-linked $\mathrm{N}$-acetylgalactosamine residue in glycoconjugates (Etzler and Kabat, 1970). The present study demonstrated that DBA selectively binds to binucleate cells (not to mononucleate epithelial cells or fibroblasts) isolated from the placenta at mid-gestation to near term. BT-1 is a trophoblastic cell line with the ability to differentiate into binucleate cells (Shimada et al., 2001; Nakano et al., 2002). However, DBA did not bind to either the mononucleate or the differentiated binucleate cells in BT-1. These results indicate that binucleate cells in vivo, but not those in BT-1, produced DBA-recognized glycoconjugates.

The results from the present study that DBA binds specifically to binucleate cells confirmed findings obtained using bovine placental tissue sections (Munson et al., 1989; Lehmann et al., 1992; Jones et al., 1994). The DBA binding to binucleate cells in bovine placental tissue occurs between day 29 and day 40 of gestation (Lehmann et al., 1992), and is maintained until near term (Munson et al., 1989; Jones et al., 1994). Binucleate cells contain a well-developed rough endoplasmic reticulum and Golgi apparatus (Björkman, 1968), and produce many glycoproteins including placental lactogen (Shimomura and Bremel, 1988), PRP-1 (Zieler et al., 1990), PAGs (Zoli et al., 1991, Green et al., 2000) and the SBU-3 antigen of chorionic villi (Lee et al., 1986). Therefore, it is conceivable that a lectin such as DBA can bind to glycans expressed by binucleate cells. In the present study, it was demonstrated that DBA-positive signals largely corresponded to binucleate cells with placental lactogen-positive and cytokeratin-negative signals in primary culture and also in intact tissue. Binucleate cells are thought to be produced by the acytokinesis of cytokeratin-positive epithelial cells in the trophectoderm layer (Wimsatt, 1951; Björkman, 1968; Klisch et al., 1999b), and then develop secretory machinery for hormone production (Wooding, 1982) with a concomitant decrease in cytokeratin expression (Lee et al., 1990; Nakano et al., 2001). The results indicate that in addition to placental lactogen and cytokeratin expression, DBA binding activity also reflects the maturity of binucleate cells.

DBA binding was recognized at the surface membrane and the cytoplasm of binucleate cells. In the cytoplasm,

PL (red) and (c) fluorescein isothiocyanate (FITC)-conjugated DBA (green). (a) Nuclei were stained with Hoechst 33342. Note both PL-positive (arrowheads) and PL-negative (arrows) binucleate cells are free from DBA staining. Scale bar represents $50 \mu \mathrm{m}$. 
DBA binding would be localized in granules of secretory vesicles, as the DBA binding was correlated with hormone synthesis of the cells marked by placental lactogen. In some placental lactogen-negative binucleate cells, DBA stained only the surface membrane of the cells. However, DBA did not seem to bind to placental lactogen because terminal positions of glycoresidues in placental lactogen are expected to be occupied by sialic acid residues (Shimomura and Bremel, 1988). The cytoplasmic staining of DBA in some placental lactogen-negative binucleate cells may be explained by the presence of heterogeneous population in hormone synthesis (Wooding et al., 1996).

Binucleate cells in culture underwent a change in shape from oval to flat within a few days, and entered a dedifferentiated state with a downregulated expression of placental lactogen (Nakano et al., 2001). Thus, the decreased staining of DBA in the cytoplasm of flattened binucleate cells may result from the depletion of glycosylated secretory vesicles. The peri-nuclear region recognized by DBA in flattened binucleate cells would be the Golgi apparatus in which the glycosylation of proteins predominantly occurs.

The binucleate cells differentiated from BT-1 were free from DBA binding in contrast to the binucleate cells in primary culture and tissue, although the cells differentiated from BT-1 have similar properties to the cells in primary culture in respect of placental lactogen production and an increased nuclear DNA content (Duello et al., 1986; Klisch et al., 1999a; Nakano et al., 2002). The present study demonstrated that the expression of cytokeratin filaments of binucleate cells in BT-1 was also downregulated. Thus, in vivo- and in vitro-derived binucleate cells were similar except for DBA binding activity. In bovine placenta, DBApositive binucleate cells are first recognized between day 29 and day 40 of gestation (Lehmann et al., 1992), although binucleate cells are already present and have secreted placental lactogen at day 17 (Flint et al., 1979). BT-1 was derived from bovine blastocysts fertilized in vitro, and retained trophectodermal properties with the expression of cytokeratin and interferon- $\tau$ (Shimada et al., 2001; Nakano et al., 2002). Interferon- $\tau$ is an anti-luteolytic factor, largely secreted from mononucleate cells of the trophectoderm at peri-implantation (day 17 of gestation in cows, Demmers et al., 2001). Thus, binucleate cells differentiated from BT-1 cell cultures may reflect those cells at the early stages of gestation.

The function of glycoconjugates recognized by DBA in binucleate cells remains to be elucidated. Another glycoprotein, the SBU-3 antigen, which is found in secretory granules and Golgi apparatus in bovine binucleate cells, is also not detected at an early stage (day 18-23), but is detected at day 30 of gestation (Morgan et al., 1989). The appearance of the SBU-3 antigen coincides with the development of the chorionic villi, implying its involvement in placentation (Morgan et al., 1989). In particular, binucleate cells show cell migration and cell fusion at the interface between the chorionic villi and maternal uterine caruncle (Wooding and Wathes, 1980; Wooding, 1982; Wooding and Beckers, 1987; Wooding et al., 1994). These glycoconjugates in granules and on the cell surface may have a role in cell recognition and cell-to-cell interaction. Further study will be needed to clarify which glycoconjugates are recognized by DBA, and also their relationship with cellular function.

In conclusion, DBA selectively binds to matured binucleate cells with placental lactogen-positive and cytokeratin-negative signals in primary culture and tissue, but not to those cells in BT-1. Thus, DBA-binding activity represents the full differentiation into binucleate cells in vivo. The onset of DBA binding in binucleate cells coincides with placentation (at about day 30 of gestation), and binucleate cells differentiated from BT-1 cell cultures may represent those cells at earlier gestation.

The authors thank the Central Meat Inspection Centre of Saitama Prefecture (Saitama, Japan) for supplying bovine placenta materials. This work was supported by grants from the Bio-oriented Technology Research Advancement Institution (BRAIN), and the Organized Research Combination System in the Science and Technology Agency of Japan. H. Nakano is a domestic research fellow supported by Japan Society for the Promotion of Science. A. Shimada is supported by a post-doctoral fellowship from the Japan Science and Technology Corporation.

\section{References}

Anthony RV, Liang R, Kayl EP and Pratt SL (1995) The growth hormone/prolactin gene family in ruminant placentae Journal of Reproduction and Fertility Supplement 49 83-95

Björkman NH (1968) Fine structure of cryptal and trophoblastic giant cells in the bovine placentome Journal of Ultrastructure Research $\mathbf{2 4}$ 249-258

Demmers KJ, Derecka K and Flint A (2001) Trophoblast interferon and pregnancy Reproduction 121 41-49

Duello TM, Byatt JC and Bremel RD (1986) Immunohistochemical localization of placental lactogen in binucleate cells of bovine placentomes Endocrinology 119 1351-1355

Etzler ME and Kabat EA (1970) Purification and characterization of a lectin (plant hemagglutinin) with blood group A specificity from Dolichos biflorus. Biochemistry 9 869-877

Flint APF, Henville A and Christie WB (1979) Presence of placental lactogen in bovine conceptuses before attachment Journal of Reproduction and Fertility $\mathbf{5 6}$ 305-308

Green JA, Xie S, Quan X, Bao B, Gan X, Mathialagan N, Beckers JF and Roberts RM (2000) Pregnancy-associated bovine and ovine glycoproteins exhibit spatially and temporally distinct expression patterns during pregnancy Biology of Reproduction 62 1624-1631

Jones CJP, Koob B, Stoddart RW, Hoffmann B and Leiser R (1994) Lectinhistochemical analysis of glycans in ovine and bovine near-term placental binucleate cells Cell and Tissue Research 278 601-610

Kessler MA, Duello TM and Schuler LA (1991) Expression of prolactinrelated hormones in the early bovine conceptus, and potential for paracrine effect on the endometrium Endocrinology 129 1885-1895

Klisch K, Hecht W, Pfarrer C, Schuler G, Hoffmann B and Leiser R (1999a) DNA content and ploidy level of bovine placentomal trophoblast giant cells Placenta 20 451-458

Klisch K, Pfarrer C, Schuler G, Hoffmann B and Leiser R (1999b) Tripolar acytokinetic mitosis and formation of feto-maternal syncytia in the bovine placentome: different modes of the generation of multinuclear cells Anatomy and Embryology $200229-237$ 
Lee CS, Gogolin-Ewens KJ and Brandon MR (1986) Comparative studies on the distribution of binucleate cells in the placentae of the deer and cow using the monoclonal antibody, SBU-3 Journal of Anatomy 147 163-179

Lee CS, Ralph MM, Gogolin-Ewens KJ and Brandon MR (1990) Monoclonal antibody (SBU-1 and SBU-3) identification of cells dissociated from the sheep placentomal trophoblast Journal of Histochemistry and Cytochemistry 38 649-652

Lehmann M, Rüsse I and Sinowatz F (1992) Nachweis von lektinbindungsstellen am trophoblast des rindes während der frühgravidität Anatomie Histologie Embryologie 21 263-270

Matamoros RA, Caamano L, Lamb SV and Reimers TJ (1994) Estrogen production by bovine binucleate and mononucleate trophoblastic cells in vitro. Biology of Reproduction 51 486-492

Morgan G, Wooding FBP, Beckers JF and Friesen HG (1989) An immunological cryo-ultrastructural study of a sequential appearance of proteins in placental binucleate cells in early pregnancy in the cow Journal of Reproduction and Fertility 86 745-752

Munson L, Kao JJ and Schlafer DH (1989) Characterization of glycoconjugates in the bovine endometrium and chorion by lectin histochemistry Journal of Reproduction and Fertility 87 509-517

Nakano H, Takahashi T, Imai K and Hashizume K (2001) Expression of placental lactogen and cytokeratin in bovine placental binucleate cells in culture Cell and Tissue Research 303 263-270

Nakano H, Shimada A, Imai K, Takezawa T, Takahashi T and Hashizume K (2002) Bovine trophoblastic cell differentiation on collagen substrata: formation of binucleate cells expressing placental lactogen Cell and Tissue Research 307 225-235

Reimers TJ, Ullmann MB and Hansel W (1985) Progesterone and prostanoid production by bovine binucleate trophoblastic cells Biology of Reproduction 33 1227-1236

Shimada A, Nakano H, Takahashi T, Imai K and Hashizume K (2001) Isolation and characterization of a bovine blastocyst-derived trophoblastic cell line, BT-1: development of a culture system in the absence of feeder cell Placenta 22 652-662

Shimomura K and Bremel RD (1988) Characterization of bovine placental lactogen as a glycoprotein with $\mathrm{N}$-linked and O-linked carbohydrate side chains Molecular Endocrinology 2 845-853

Takahashi T, Aso H and Hashizume K (2001) Immunological and biological activities of bovine placental lactogen in placental explant culture Journal of Reproduction and Development 47 63-67
Wango EO, Heap RB and Wooding FBP (1991) Progesterone and 5 $\beta$ pregnanediol production by isolated fetal placental binucleate cells from sheep and goats Journal of Endocrinology 129 283-289

Wimsatt WA (1951) Observations on the morphogenesis, cytochemistry and significance of the binucleate giant cells of the placenta of ruminants American Journal of Anatomy 89 233-281

Wooding FBP (1982) The role of the binucleate cell in ruminant placental structure Journal of Reproduction and Fertility Supplement 31 31-39

Wooding FBP and Beckers JF (1987) Trinucleate cells and the ultrastructural localisation of bovine placental lactogen Cell and Tissue Research 247 667-673

Wooding FBP and Flint APF (1994) Placentation. In Marshall's Physiology of Reproduction Fourth Edn Vol. 3, pp 233-460 Ed. GE Lamming. Chapman and Hall, London

Wooding FBP and Wathes DC (1980) Binucleate cell migration in the bovine placentome Journal of Reproduction and Fertility 59 425-430

Wooding FBP, Morgan G, Brandon MR and Camous S (1994) Membrane dynamics during migration of placental cells through trophectodermal tight junctions in sheep and goats Cell and Tissue Research 276 387-397

Wooding FBP, Morgan G, Monaghan S, Hamon M and Heap RB (1996) Functional specialization in the ruminant placenta: evidence for two populations of fetal binucleate cells of different selective synthetic capacity Placenta 17 75-86

Zieler CG, Kessler MA and Schuler LA (1990) Characterization of a novel prolactin-related protein from bovine fetal placenta Endocrinology 126 2377-2382

Zoli AP, Beckers JF, Wouters-Ballman P, Closset J, Falmagne P and Ectors F (1991) Purification and characterization of a bovine pregnancyassociated glycoprotein Biology of Reproduction 45 1-10

Zoli AP, Demez P, Beckers JF, Reznik M and Beckers A (1992) Light and electron microscopic immunolocalization of bovine pregnancyassociated glycoprotein in the bovine placentome Biology of Reproduction 46 623-629

Received 8 April 2002.

First decision 23 May 2002.

Revised manuscript received 25 June 2002.

Accepted 12 July 2002. 